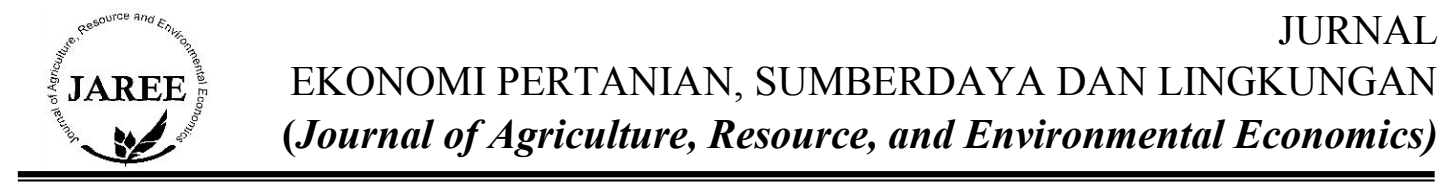

\title{
Analisis Kualitatif Nilai Ekspor Migas Indonesia Dan Kepemilikan Blok Migas Oleh Perusahaan Asing Di Indonesia
}

Prima Gandhi ${ }^{1)}$

INFO NASKAH :

Proses Naskah:

Diterima 4 Februari 2014

Diterima hasil revisi 12 Maret 2014

Diterima untuk terbit 15 April 2014

Terbit April 2014

Keywords :

Export

Oil Gas Block

Resource Economics

\begin{abstract}
The post conference of Time Life Corp in Geneva and the enactment of the Foreign Investment Act of 1967, foreign corporations began to exploit oil and gas in Indonesia. At first, the foreign corporation only managed the upstream oil and gas business. However, the oil and gas Act number 22 of 2001 made the foreign corporations do the business in the downstream sector. Data from the Ministry of Energy and Mineral showed that there was 69.9 percent of foreign domination in the Indonesian oil and gas industry. Other data showed that
\end{abstract}

the value of exports of oil and gas in Indonesia decreased by the end of July 2013. The existence of these two phenomena of economic resources made the author try to examine the relation between the ownership of oil and gas blocks by foreign companies and the level of oil and gas export value in Indonesia using qualitative methods with critical paradigm. As a result, the number of oil and gas companies in Indonesia was influenced by the attitudes and government regulations, the state of technology and state of the Indonesian economy. The low value of oil and gas exports was as the result of exporting crude oil price with lower pricecompared to that of processed oil. The existence and the number of foreign oil companies influenced the level of oil and gas export value of Indonesia. The more dominated growing number of foreign companies in Indonesia, the less export value of the Indonesian oil and gas would be.

\section{PENDAHULUAN}

Menjelang pemilihan presiden tahun 2014, migas menjadi perhatian khusus calon presiden dan wakil presiden. Dalam visi dan misi yang disampaikan ke Komisi Pemilihan Umum, Calon presiden no urut satu Prabowo-Hatta berjanji mengembalikan tata kelola migas nasional sesuai pasal 33 UUD 1945 dengan penyelesaian revisi UU Migas. Sementara pasangan no urut dua Jokowi-Jusuf Kalla dalam visi misinya menyampaikan akan meraih kedaulatan energi berbasis kepentingan nasional. Mereka merancang terobosan strategi untuk menjaga dan meningkatkan produksi minyak bumi baik dalam jangka pendek maupun

Prima Gandhi

Departemen Ekonomi Sumber Daya dan Lingkungan, Institut Pertanian Bogor.

Email : Stijac3@yahoo.com 
jangka panjang. Fakta di atas menunjukkan bahwa sumber daya alam masih penting di Indonesia. Penting karena merupakan salah satu modal pembangunan. Selama lebih dari empat dasawarsa sumber daya alam sudah menjadi mesin pertumbuhan ekonomi Indonesia. Bahkan pada masa orde baru sumber daya alam minyak, hutan dan sumber daya mineral menjadi ujung tombak dalam memacu pertumbuhan ekonomi Indonesia (Fauzi, 2014). Hingga saat ini gas alam memiliki nilai ekonomis yang cukup tinggi sehingga termasuk dalam jenis barang tambang yang diunggulkan Indonesia untuk memacu pertumbuhan ekonomi selain minyak bumi. Industri minyak dan gas ( Migas) ditetapkan pemerintah sebagai Industri strategis. Indonesia merupakan negara eksportir gas alam terbesar ke delapan di dunia (EIA, 2011). ${ }^{1 .}$ Dalam UU No. 44/Prp/1960 tentang pertambangan minyak dan gas bumi dikatakan bahwa "Sumber daya Migas tidak saja mempunyai fungsi yang amat penting untuk pembangunan masyarakat adil dan makmur, namun produksi Migas juga merupakan cabang-cabang produksi yang amat penting bagi negara dan menguasai hajat hidup orang banyak, selain itu Migas juga mempunyai arti khusus untuk pertahanan nasional dan persoalan- persoalan mengenai Migas mengandung aspek- aspek internasional".

Sumber daya alam Indonesia berupa minyak bumi dan gas alam saat ini mayoritas dikuasai oleh pihak asing. Hal ini dikarenakan besarnya modal yang dibutuhkan dan minimnya sumber daya manusia (SDM) yang menguasai teknologi terkait proses eksploitasi Migas. Pasca konferensi Time Life Corp di Geneva dan diberlakukannya UU Penanaman Modal Asing pada tahun 1967 korporasi Asing mulai mengeksploitasi Migas di Indonesia. Awalnya beberapa korporasi multinasional Migas seperti Total, British Petroleum, Exxon Mobil hanya mengelola sektor hulu bisnis migas. Namun, UU nomor 22/2001 tentang migas, membuat korporasi asing berpeluang untuk berbisnis di sektor hilir. Buktinya adalah saat ini SPBU Shell, Petronas dan Total sudah berdiri di beberapa kota besar Indonesia. Akhir Mei 2009, data Departemen ESDM menunjukkan 69,9 persen dominasi asing dalam industri migas Indonesia, sekitar 70 persen di antaranya perusahaan asal AS seperti Chevron, Conoco Philips dan Exxon Mobil. Perusahaan migas nasional hanya sebesar 29,1 persen dalam industri migas. Khusus untuk sektor gas alam, laporan dari Energy Information Administration (EIA) pada Januari 2008 menyatakan bahwa 90 persen dari total produksi gas alam Indonseia berasal dari $6 \mathrm{MNC}$ yakni, Total (30 persen), Exxon Mobil(17 persen), Vico (BP-Eni joint venture 11 persen), Conoco Philips (11 persen), BP (6 persen) dan Chevron (4 persen).

Dari keenam MNC tersebut, 3 diantaranya berasal dari AS dan menguasai 32 persen produksi gas alam Indonesia. ${ }^{2}$ Sementara, Wahana Lingkungan Hidup (Walhi) mencatat perusahaan migas asing menguasai 49,65 persen $(95,45$ juta hektar) luas lahan konsesi migas Indonesia, dari total luas daratan wilayah Indonesia yang mencapai 192,257 juta hektar. Perusahaan migas asing menguasai 329 blok migas. Data dari Direktorat Jenderal Minyak dan Gas Bumi Ditjen Migas Departemen Energi dan Sumber Daya Mineral memperlihatkan bahwa perusahaan migas asing menguasai 65 persen dari total blok migas di Indonesia. 10,73 persen dikuasai oleh konsorsium perusahaan asing dan lokal. Sisanya perusahaan nasional dengan 24,27 persen. Nilai ekspor migas di Indonesia mengalami penurunan pada akhir Juli 2013. Penurunan ini dipicu oleh turunnya ekspor minyak mentah Indonesia. Namun harga minyak mentah Indonesia di pasar dunia tercatat mengalami peningkatan USD 3.15 per barel pada periode Juni-Juli 2013. Secara kumulatif, nilai ekspor migas Indonesia pada Januari hingga Juli 2013 sebesar USD 18,6 miliar, menurun 19,7\% dari nilai ekspor migas Indonesia periode yang sama tahun sebelumnya (BPS, 2013). ${ }^{3}$

\footnotetext{
EIA. U.S Energy Information and Administration. USA. Annual Energy Review 2011.

Berdikari.2013. Manipulasi Para Imperalis Minyak.

http://www.berdikarionline.com/kabarrakyat/20120531/manipulasi-para-imperialis

minyak.html\#ixzz2kzdo7dDDArtikel Online) diakses tanggal 18 Februari 2013

Ekspor Migas. Badan Pusat Statistik Indonesia. 2013 diakses dari www.bps.go.id
} 
Adanya dua fenomena yaitu kepemilikan blok migas oleh perusahaan asing yang cukup besar dan nilai ekspor migas di Indonesia membuat penulis mencoba meneliti keterkaitan besarnya kepemilikan blok migas oleh perusahaan asing dengan tingkat ekspor migas di Indonesia dengan metode kualitatif dan deskriftif dengan paradigma kritis.

\section{Tujuan Penelitian}

Penelitian ini secara umum bertujuan menganalisis keterkaitan besarnya kepemilikan blok migas oleh perusahaan asing dengan tingkat ekspor migas di Indonesia. Secara khusus penelitian ini bertujuan untuk:

1. Mengetahui hubungan besarnya kepemilikan blok migas oleh perusahaan asing dengan tingkat ekspor migas di Indonesia.

2. Menganalisis sumber perubahan tingkat ekspor migas di Indonesia

3. Mengidentifikasi kebijakan terkait perijinan kepemilikan blok migas oleh perusahaan asing dan tingkat nilaiekspor migas serta implikasinya.

Ruang lingkup penelitian ini adalah negara Indonesia dengan menggunakan data sekunder dan tinjauan dari buku, makalah, jurnal dan literatur sekunder lainnya.

\section{METODE PENELITIAN}

\section{Analisis Deskriptif \\ Neo Imperalisme}

Neo Imprealisme adalah suatu konsep berupa siklus yang dibuat dan digunakan negara maju untuk mengambil keuntungan sebesar-besarnya atas negara berkembang/miskin, yang mana aktifitas dalam siklus tersebut dikendalikan dan dibuat dengan rapih. Harapan dari siklus ini adalah timbulnya ketergantungan dari negara yang di eksploitasi. Neo imperialisme global tidak seperti imprealisme klasik dimana terjadi pendudukan secara langsung (kecuali dalam keadaan khusus pada kasus di Afganistan dan Iraq). Neo imprerialisme menggunakan instrumen international trade (perdagangan internasional) untuk mendapatkan keuntungan sebesar besarnya. Tujuanya dari imprealisme (klasik atau neo) tetap sama yaitu melanggengkan hegemoni global negara barat.

\section{Teori Dependensia}

Teori dependensia diperkenalkan oleh beberapa ilmuwan Amerika Latin antara lain: Andre Gundre Frank, Paul Baran, Celso Furtado, Enzo Faletto, Fernando Henrique Cardoso, Marini, Oswaldo Sunkel, Theotonio Dos Santos. Kedua orang diawal adalah ilmuwan non Amerika Latin yang sama-sama mengembangkan teori dependensia. Furtado dan Sunkel dikenal sebagai pelopor Teori Dependensia.

Celso Furtado adalah ekonom Brasil yang pada awalnya menganut paham modernisasi dan tergabung dalam program Entrepreneurship and Competitiveness in Latin America (ECLA). Awalnya Ia percaya bahwa masalah utama negara berkembang adalah kurangnya modal. Atas dasar itu, untuk memecahkan masalah permodalan, dilakukanlah substitusi impor. Optimisme Furtado timbul terhadap pertumbuhan industri di Brasil pasca dilakukan substitusi impor. Namun, seiring jalannya waktu pembangunan yang terjadi di Brasil justru melahirkan kudeta militer di Brasil. Furtado pun kecewa dan pesimis, karena pembangunan yang menitikberatkan pada pertumbuhan industri itu menciptakan ketergantungan negaranya pada pihak asing. Sejak peristiwa kudeta militer di Brasil, Furtado meninggalkan Brasil dan pindah ke Paris untuk menerukan analisis terhadap pertumbuhan ekonomi (pembangunan) di negara Amerika Latin. Hasil pemikirannya membawa usulan yaitu negara berkembang harus mengambil sikap mandiri. Pemerintah negara berkembang harus berani berjuang merestrukturisasi seluruh sektor ekonomi sehingga teknologi modern harus disebarluaskan ke seluruh lapisan sektor produksi. Sebab menurut Furtado, hal inilah yang akan membuat pemerataan distribusi pendapatan. 


\section{Perdagangan Internasional}

Perdagangan internasional dapat diartikan sebagai transaksi dagang antar subyek ekonomi negara yang satu dengan subyek ekonomi negara yang lain, baik mengenai barang maupun jasa-jasa. Adapun subyek ekonomi yang dimaksud adalah penduduk yang terdiri dari warga Negara biasa, perusahaan ekspor, perusahaan impor, perusahaan industry, perusahaan Negara ataupun departemen pemerintah yang dapat dilihat dari neraca perdagangan. Selain itu ilmu perdagangan internasional merupakan bagian dari ilmu ekonomi yang mempelajari dan menganalisis saling ketergantungan antar negara. Ilmu ini menganalisis arus barang, jasa, pembayaran-pembayaran antara suatu negara dengan negara lain di dunia, kebijakan yang mengatur arus tersebut serta pengaruhnya pada kesejahteraan negara (Rina, 2009). ${ }^{4}$

Pada dasarnya ada dua teori yang menerangkan tentang timbulnya perdagangan internasional :

\section{Teori Klasik}

Penganut merkantilis mengatakan bahwa satu-satunya cara bagi suatu negara untuk menjadi kaya dan kuat adalah dengan melakukan sebanyak mungkin ekspor dan sedikit mungkin impor. Surplus ekspor yang dihasilkan selanjutnya akan dibentuk dalam aliran emas atau logam-logam mulia (emas dan perak). Semakin banyak emas dan perak yang dimiliki oleh suatu negara maka akan semakin kaya dan kuat negara tersebut. Berdasarkan teori itu, pemerintah dipaksa menggunakan seluruh kekuatannya untuk mendorong ekspor dan mengurangi serta membatasi impor (khususnya barang-barang mewah). Namun karena setiap negara tidak secara simultan dapat menghasilkan surplus ekspor dan jumlah logam mulia adalah tetap pada satu saat tertentu, maka sebuah negara hanya dapat memperoleh keuntungan dengan mengorbankan negara lain.

Adam Smith berpendapat bahwa sumber tunggal pendapatan adalah produksi hasil tenaga kerja serta sumber daya ekonomi. Ini berarti Adam Smith sependapat dengan doktrin merkantilis yang menyatakan bahwa kekayaan suatu Negara dicapai dari surplus ekspor. Kekayaan negara akan bertambah berbandinglurus dengan skill, efisiensi tenaga kerja yang digunakan (sesuai dengan persentase penduduk yang melakukan pekerjaan tersebut). Smith mengatakan suatu negara akan mengekspor barang tertentu karena negara tersebut bisa menghasilkan barang dengan biaya yang mutlak dalam produksi barang tersebut. Hal ini membuat Adam Smith mendefinisikan keunggulan mutlak merupakan kemampuan suatu negara untuk menghasilkan suatu barang dan jasa per unit dengan menggunakan sumber daya yang lebih sedikit dibandingkan kemampuan negara-negara lain.

\section{Teori Modern}

J.S. Mill menyatakan bahwa suatu negara akan menghasilkan dan kemudian mengekspor suatu barang yang memiliki comparative advantage terbesar dan mengimpor barang yang dimiliki comparative disadvantage (suatu barang yang dapat dihasilkan dengan lebih murah dan mengimpor barang yang kalau dihasilkan sendiri memakan ongkos yang besar). David Ricardo (1772-1823) seorang tokoh ekonomi klasik menyatakan bahwa nilai penukaran ada jikalau barang tersebut memiliki kegunaan. Dengan demikian proses tukar menukar barang dapat terjadi bilamana barang tersebut dapat digunakan. Seseorang akan membuat sesuatu barang karena barang itu memiliki nilai guna yang dibutuhkan oleh orang. Kemudian David Ricardo juga membuat perbedaan antara barang yang dapat dibuat dan atau diperbanyak sesuai dengan kemauan orang, dilain pihak ada barang yang sifatnya terbatas ataupun barang monopoli (misalnya lukisan dari pelukis ternama, barang kuno, daun tembakau yang hanya tumbuh di lereng gunung tertentu dan sebagainya). Heckscher-Ohlin menjelaskan beberapa pola perdagangan dengan baik, negara-negaracenderung untuk mengekspor barang-barang yang menggunakan faktor produksi yang relative melimpah

\footnotetext{
4 Oktaviani, R dan Novianti. 2009. Teori Perdagangan Internasional dan Aplikasinya di Indonesia. Departemen Ilmu Ekonomi FEM IPB, Bogor.
} 
secara intensif. Menurut teori Heckscher-Ohlin, suatu negara akan melakukan perdagangan dengan negara lain disebabkan negara tersebut tidak memiliki keunggulan komparatif yaitu keunggulan dalam teknologi dan keunggulan produksi. Basis dari keunggulan komparatif adalah pertama, faktor endowment, yaitu kepemilikan faktor-faktor produksi didalam suatu negara. Kedua,faktor intensitas, yaitu teknologi yang digunakan didalam proses produksi

Secara konsep perdagangan internasional adalah mendorong industrialisasi, kemajuan transportasi, globalisasi, dan kehadiran perusahaan multinasional. Kajian tentang perdagangan internasional semakin penting karena pengaruh globalisasi ekonomi dunia yang dicirikan oleh hal-hal sebagai berikut pertama, keterbukaan ekonomi terutama dengan adanya liberalisasi pasar dan arus uang serta transfer teknologi secara internasional. Kedua,keterkaitan dan ketergantungan ekonomi, keuangan, perdagangan dan industri antar negara atau perusahaan yang ditunjukkan oleh adanya pembentukan perusahaan multinasional dan kecenderungan integrasi ekonomi regional. Ketiga, persaingan yang semakin ketat antarnegara ataupun perusahaan untuk meningkatkan produktivitas, efisiensi dan efektivitas yang optimal. ${ }^{5}$

Adanya perdagangan internasional akan memberikan dampak positif pada suatu negara berupa: (i) sarana untuk meningkatkan kemakmuran masyarakat melalui proses pertukaran; (ii) spesialisasi dan pembagian kerja membuat suatu negara dapat mengekspor komoditi yang diproduksi dengan biaya yang lebih murah untuk dipertukarkan dengan barang yang dihasilkan oleh negara lain, yang jika diproduksi di dalam negeri membutuhkan biaya yang mahal; (iii) perluasan pasar produk dan pergeseran kegiatan produksi membuat suatu negara mendapat keuntungan berupa peningkatan pendapatan nasional yang akan meningkatkan output dan laju pertumbuhan ekonomi; (iv) dapat mendorong kenaikan investasi dan tabungan melalui alokasi sumber-sumber yang lebih efisien.

\section{Liberalisasi Perdagangan}

Pengertian dari kebijakan liberalisasi perdagangan adalah kebijakan perdagangan yang diambil suatu negara yang mencerminkan pergerakan ke arah yang lebih netral, liberal atau terbuka. Secara khusus, perubahan ke arah yang semakin netral tersebut meliputi penyamaan insentif (rata-rata) diantara sektor-sektor perdagangan. Suatu negara dianggap menjalankan kebijakan liberalisasi perdagangan apabila terjadi pengurangan tingkat intervensi secara keseluruhan serta pengurangan hambatan-hambatan dalam perdagangan. Selain itu, kebijakan yang liberal juga dapat ditandai melalui semakin pentingnya peranan perdagangan dalam perekonomian.

Ekspansi ekspor berhubungan dengan kebijakan liberalisasi yang identik dengan usaha peningkatan ekspor untuk meningkatkan pendapatan nasional. Alasan diberlakukannya ekspansi ekspor adalah memungkinkan terciptanya arus modal internasional dan jaringan pertukaran keterampilan, teknologi, dan manajemen. Strategi tersebut juga akan menciptakan kesempatan kerja yang lebih besar bila dibandingkan dengan substitusi impor. Hal ini dikarenakan ekspansi ekspor lebih bersifat padatkarya dan sangat berperan dalam penyerapan tenaga kerja. Keuntungan dari ekspansi ekspor adalah dapat meningkatkan pemasukan negara berupa cadangan devisa. Namun, strategi ini berpotensi meningkatkan pengeluaran untuk impor seiring dengan kenaikan pendapatan suatu negara yang pada akhirnya akan menimbulkan defisit pada neraca perdagangan.

Kebijakan dalam rangka liberalisasi juga dapat dikelompokkan menjadi dua yaitu yang dilakukan secara global dan unilateral, dan yang dilakukan secarabilateral atau regional. Kebijakan yang berlaku global berkaitan dengan kesepakatan yang diputuskan di WTO dan yang unilateral adalah kebijakan yang secara sepihak dilaksanakan oleh negara

5 Hady, H. 2001. Ekonomi Internasional : Teori dan Kebijakan Perdagangan Internasional. Buku kesatu. Ghalia Indonesia. Jakarta 
tersebut. Kebijakan regional atau bilateral adalah kebijakan yang dilaksanakan berdasarkan pada kesepakatan secara bilateral atau regional yang biasanya berada dalam suatu perjanjian perdagangan baik bilateral maupun regional.

\section{Ekspor}

Ekspor adalah kegiatan sistem perdagangan dengan cara mengeluarkan barang-barang dari dalam negeri keluar negeri dengan memenuhi ketentuan yang berlaku. Ekspor merupakan total barang dan jasa yang dijual oleh sebuah negara ke negara lain, termasuk diantara barang-barang, asuransi, dan jasa-jasa pada suatu tahun tertentu (Priadi, 2000). Fungsi penting komponen ekspor dari perdagangan luar negeri adalah negara memperoleh keuntungan dan pendapatan nasional naik, yang pada gilirannya menaikkan jumlah output dan laju pertumbuhan ekonomi. Dengan tingkat output yang lebih tinggi lingkaran setan kemiskinan dapat dipatahkan dan pembangunan ekonomi dapat ditingkatkan (Jhingan, 2000).

Menurut Mankiw, Ekspor adalah berbagai macam barang dan jasa yang diproduksi di dalam negeri lalu dijual di luar negeri . Ditinjau dari sudut pengeluaran, ekspor merupakan salah satu faktor terpenting dari Gross Nasional Product (GNP), sehingga dengan berubahnya nilai ekspor maka pendapatan masyarakat secara langsung juga akan mengalami perubahan. Di lain pihak, tingginya ekspor suatu negara akan menyebabkan perekonomian tersebut akan sangat sensitif terhadap keguncangan-keguncangan atau fluktuasi yang terjadi di pasaran internasional maupun di perekonomian dunia (Irham dan Yogi, 2003).

Suatu negara dapat mengekspor barang produksinya ke negara lain apabila barang tersebut diperlukan negara lain dan mereka tidak dapat memproduksi barang tersebut atau produksinya tidak dapat memenuhi keperluan dalam negeri. Faktor yang lebih penting lagi adalah kemampuan dari negara tersebut untuk mengeluarkan barang-barang yang dapat bersaing dalam pasaran luar negeri. Maksudnya, mutu dan harga barang yang diekspor tersebut haruslah paling sedikit sama baiknya dengan yang diperjualbelikan dalam pasaran luar negeri. Cita rasa masyarakat di luar negeri terhadap barang yang dapat diekspor ke luar negara sangat penting peranannya dalam menentukan ekspor sesuatu negara. Secara umum bisa dikatakan bahwa semakin banyak jenis barang yang mempunyai keistimewaan yang sedemikian yang dihasilkan oleh suatu negara, semakin banyak ekspor yang dapat dilakukan (Sukirno, 2008).

Menurut Mankiw (2006), berbagai faktor yang dapat mempengaruhi ekspor,impor, dan ekspor neto suatu negara, meliput pertama, selera konsumen terhadap barang-barang produksi dalam negeri dan luar negeri. Kedua, harga barang-barang di dalam dan di luar negeri. Ketiga, kurs yang menentukan jumlah mata uang nasional yang dibutuhkan untuk membeli mata uang asing. Keempat, pendapatan konsumen di dalam negeri dan luar negri. Kelima, ongkos angkutan barang antar negara. Keenam, kebijakan pemerintah mengenai perdagangan internasional.

\section{Multi National Corporation atau Perusahaan Multinasional (MNC)}

Perusahaan multinasional (MNC) adalah sebuah perusahaan internasional atau transnasional yang berkantor pusat di satu negara tetapi memiliki kantor cabang di baik di negara maju maupun negara berkembang. MNC merupakan aktor baru (non-state) dalam konstelasi internasional yang perkembangannya menarik para scholars dalam hubungan internasional untuk menelitinya. ${ }^{6}$ Perusahaan multinasional (MNC) dikatakan oleh banyak ahli lahir pasca Perang Dunia ke II.

Magdoff memandang kelahiran MNC sebagai sebuah evolusi terbaru dari dunia kapitalis. Kelahiran MNC ini dapat dipahami dari catatan-catatan yang ditulis oleh Marx mengenai perilaku-perilaku kaum kapitalis (Magdoff, 1978: 165). Menurut Marx, inti sentral

Lairson, Thomas D and D Skidmore., 2003. "The Political Economy of American Hegemony: 1938-1973", ins: International Political Economy: the Struggle for Power and Wealth. Orlando: Harcourt Brace College Publishers. Ch. 4. Hlm 61 
dari kelahiran MNC, ditandai oleh beberapa faktor, diantaranya adalah (1) Kondisi perusahaan kapitalis memaksa perusahaan memperluas jaringan mereka. Perkembangan produksi kapitalis yang semakin tumbuh signifikan, membuat mereka "dipaksa" untuk terus meningkatkan jumlah modal kapital mereka. (2) Proses akumulasi modal dapat dilakukan melalui dua bentuk yang saling berkaitan satu sama lain yaitu penyebaran produksi dalam skala besar dan kombinasi perusahaan melalui merger dan akuisisi. Dan (3) pasar menyediakan dasar dan elemen penting dari produksi kapitalis. Faktanya adalah, kapitalisme lahir di masa revolusi industri pada abad ke-16 dan awal abad ke-17. Sebuah revolusi yang dihasilkan pasar global, berpusat pada kebutuhan dan keinginan bangsa-bangsa eropa barat. Inti utama atribut dari MNC sendiri adalah perluasan investasi, konsentrasi kekuasaan perusahaan, dan pertumbuhan pasar dunia (Magdoff,1978). ${ }^{7}$

Upaya untuk mengatasi kemunculan Masyarakat Ekonomi Eropa (MEE) dan kesulitan pembayaran juga ikut mempengaruhi perkembangan ekonomi Amerika Serikat dan dunia. Peristiwa ini memunculkan aktor-aktor transnasional baru yaitu MNC dan munculnya pasar kapital ekonomi internasional yang baru. Fitur utama dari MNC adalah investasi langsung ke luar negeri yang dirancang untuk menentukan dan mengatur produksi dan atau unit distribusi. Pergerakan kekuatan ekonomi Amerika Serikat (AS) paska Perang Dunia II semakin pesat dimana 52\% investasi luar negeri Amerika berada dilakukan oleh perusahan MNC Amerika Serikat (Lairson \& Skidmore, 2003). ${ }^{8}$ Kelahiran MNC sendiri merupakan salah satu alat hegemoni AS disektor perekonomian saat itu dan memiliki pengaruh yang besar bagi perkembangan ekonomi dunia (Lairson \& Skidmore, 2003: 83).

Menurut Magdoff, terdapat beberapa faktor utama lainnya yang menyebabkan kemunculan perusahaan MNC Amerika Serikat dan bentuk baru dari operasi kapitalis internasional, diantaranya adalah (1) sistem pembayaran internasional, dimana dulunya sistem pembayaran internasional berpatokan pada pasar uang London, ketika Inggris masih menghegemoni di abad ke-19. Namun, setelah Perang Dunia II setelah munculnya sistem pembayaran internasional baru yang terangkum dalam Bretton Woods System memberikan kesempatan lebih bagi Amerika Serikat dalam mengembangkan investasi luar negeri mereka dalam pasar internasional (Lairson \& Skidmore, 2003)..$^{9}$ (2) Adanya kesejahteraan dan pembangunan ekonomi yang didorong oleh Marshall Plan, yang telah dilakukan sebagian besar untuk membangun kembali dan memperkuat kapitalisme Eropa sebagai sekutu politik dan militer.

Amerika Serikat dan Eropa berhasil meningkatkan jumlah perusahaan-perusahaan multinasional (3) Program militer dan ekonomi dalam negeri memberikan pengaruh besar bagi Amerika Serikat untuk menanamkan modal investasi di negara lain. (4) Perang Dunia II membangkitkan sebuah perubahan baru dalam dunia bisnis dan teknologi yang juga memberikan dampak yang signifikan bagi pertumbuhan MNC itu sendiri (Lairson \& Skidmore, 2003)..$^{10}$

Terlepas dari segala perkembangan MNC terutama paska Perang Dunia II, muncul kontroversi dari kelahiran MNC itu sendiri. Perkembangan MNC akan menyebabkan peran negara sebagai aktor utama dalam konstelasi internasional menurun. Terdapat dua alasan yang menyatakan bahwa MNC mengikis peran negara diantaranya adalah definisi kepentingan nasional dan kemampuan negara dalam mengontrol ekonomi. Pertama, definisi kepentingan nasional dimana pengaruh asing akan merubah konsep kepentingan nasional dalam wilayah suatu negara. Salah satu pengaruh asing yang dapat mempengaruhi perubahan

\footnotetext{
7 Magdoff, Harry. 1978. "The Multinational Corporation and Development - A Contradiction?" dalam Imperialism: from the Colonial Age to the Present. New York: Monthly Preview Press, hlm166 - 168.

8 Lairson, Thomas D and D Skidmore., 2003. "The Political Economy of American Hegemony: 1938-1973", ins: International Political Economy: the Struggle for Power and Wealth. Orlando: Harcourt Brace College Publishers. Ch. 4, hlm 170.

9 Lairson, Thomas D and D Skidmore, 2003, hlm 171.

10 Lairson, Thomas D and D Skidmore, 2003, hlm 172-174.
} 
kepentingan nasional adalah kedatangan MNC itu sendiri. ${ }^{11}$ Dan yang kedua adalah kedaulatan negara dimana peran negara mulai menurun dalam hal mengatur kondisi perekonomian dan moneter dalam negeri mereka seperti, mengontrol suku bunga, kebijakan fiskal, dll (Lairson \& Skidmore, 2003). ${ }^{12}$

Permasalahan-permasalahan seperti ini lebih banyak ditemui di negara-negara berkembang dan sedang berkembang. MNC sebagai perwakilan pihak asing memiliki kekuatan dalam menciptakan keseimbangan kekuatan ekonomi dan kekuatan di negara tersebut. Salah satu bentuk kontribusi MNC di negara-negara duni ketiga tersebut salah satunya adalah meningkatkan arus impor dan ekspor (Lairson \& Skidmore, 2003). ${ }^{13}$

Berdasarkan teori di atas, analisis deskriptif dalam penelitian ini mengenai hubungan persentase perusahaan dengan jumlah ekspor di Indonesia mulanya harus diketahui terlebih dahulu apa yang memegaruhi jumlah persentase perusahaan migas asing di Indonesia.

Persentase perusahaan migas asing di Indonesia dipengaruhi oleh :

a. Sikap dan regulasi pemerintah

Sikap pemerintah yang sangat terbuka terhadap investasi asing di bidang migas, membuat mudahnya perusahaan asing berinvestasi di Indonesia. Pelaksanaan perundangundangan dalam praktek yang tidak sesuai dengan aturan sebenarnya menjadikan perundang-undangan bukanlah landasan pemerintah dalam membuat kebijakan. Sikap Rent Seeking dan Seizing aktor-aktor migas di Indonesia (BP Migas dan Pertamina) ikut melanggengkan keberadaan perusahan migas asing di Indonesia. Hal ini dibuktikan dengan tertangkapnya kepala SKK Migas Prof. Rudi R oleh KPK pada akhir tahun 2013.

b. Keadaan teknologi

Masih rendahnya teknologi yang tersedia dalam negeri, menyulitkan pengolahan bahan baku menjadi barang olahan yang lebih spesifik. Potensi asing dalam memproduksi dan menguasai migas lebih besar karena memilik kondisi teknologi di bidang migas yang lebih canggih dari yang Indonesia miliki.

c. Keadaan ekonomi

Investasi merupakan salah satu komponen dari pendapatan nasional, Produk Nasional Bruto (PDB) atau Gross Demestic Product (GDP) dalam ekonomi makro. Investasi berkorelasi positif dengan pendapatan negara (GDP). Jika pendapatan negara tinggi maka kemakmuran penduduk negara akan baik, sebaliknya jika pendapatan negara rendah maka akan terjadi kemiskinan penduduk. Di negara sedang berkembang (NSB) dan negara berkembang (NB) seperti Indonesia dengan jumlah penduduk besar, rasio investasi dalam negeri terhadap jumlah penduduk angkanya relatif kecil. Untuk meningkatkan rasio investasi ini, pemerintah Indonesia mempunyai solusi mengundang investor asing untuk berinvestasi.

Keadaan ekonomi dan neraca perdagangan defisit yang membuat pemerintah memudahkan investor asing untuk berinvestasi di dalam negeri. Tujuannya untuk menambah uang kas Negara melalui pajak atau kesepakatan kerjasama ekonomi lainnya. Perlu dilakukan suatu analisis ekonomi politik, untuk mengaetahu faktor-faktor apa yang memengaruhi perizinan perusahaan migas asing dalam menanamkan modalnya di Indonesia. Dalam jangka pendek/menengah, investasi asing dapat membantu memenuhi segala sesuatu bagi NSB/NB. Namun, dalam jangka panjang investasi asing melahirkan dampak sosial, ekonomi dan ekologis bagi NSB/NB.

\footnotetext{
Magdoff, Harry. 1978, hlm 186

Magdoff, Harry. 1978, hlm 188.

Magdoff, Harry. 1978, hlm 190.
} 


\section{Kerangka Pemikiran}

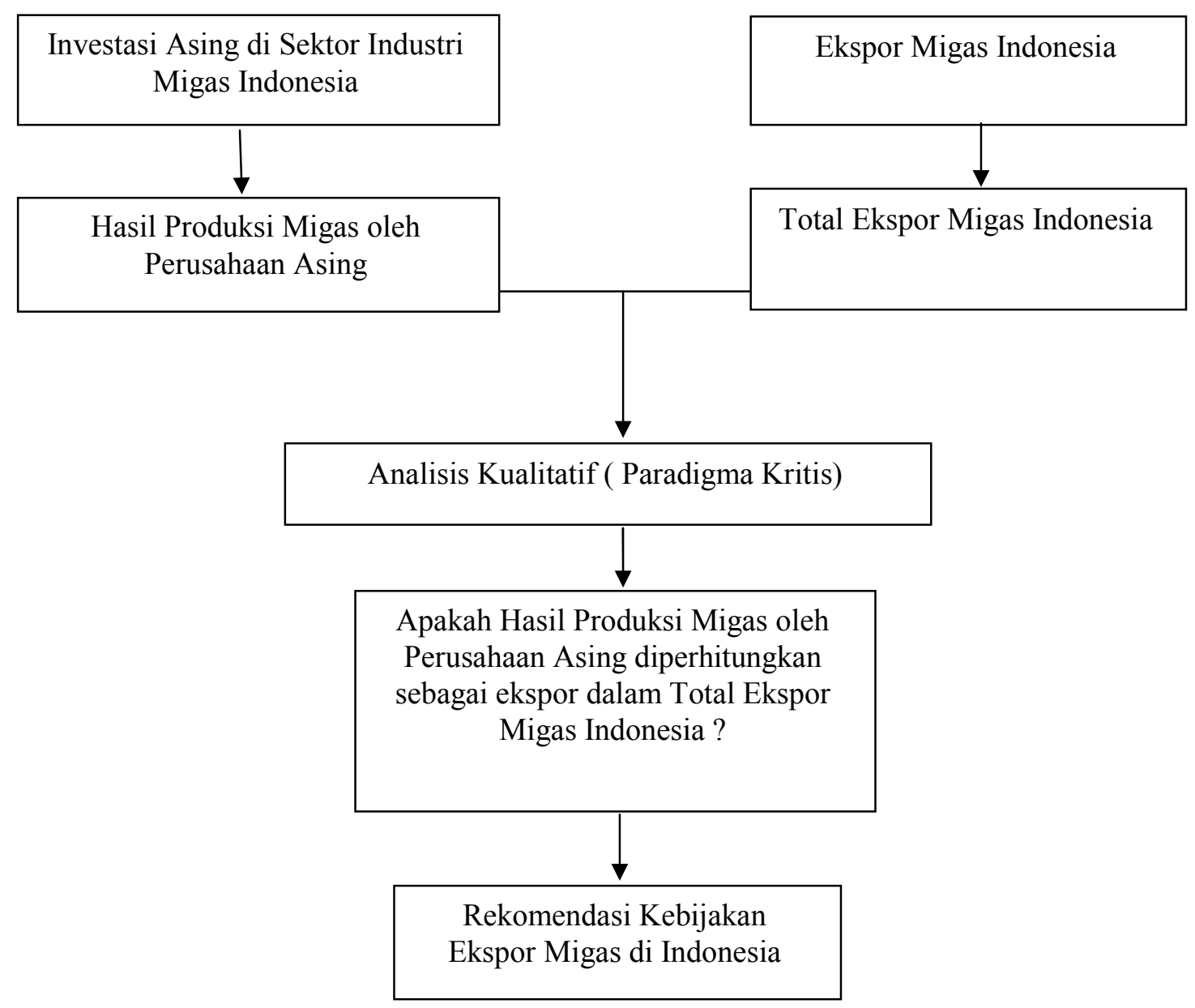

Gambar 1. Kerangka Pemikiran Penelitian

Penelitian tentang keterkaitan antara Investasi Asing di Sektor Migas dan Ekspor Migas Indonesia digambarkan dalam diagram kerangka pemikiran pada Gambar diatas.

\section{HASIL DAN PEMBAHASAN}

\section{Persentase Kepemilikan Perusahaan Asing Terhadap Blok Migas Indonesia}

Pelaku utama industry minyak dan gas alam dunia disebut Supermajor. Supermajor adalah istilah bagi Big IOC (International Oil Company) yang memiliki pengaruh hebat dalam kancah ekonomi politik global. Supermajor terdiri dari 6 perusahaan IOC yang dahulunya berjumlah 7 (The Seven Sister). Nama lain dari supermajor adalah Big Oil. Supermajor terdiri dari Exxon Mobil, Royal Dutch Shell, British Petroleum (BP), Chevron Corp, Conoco Phillips, dan Total. Ke enam Supermajor ini pun beraktivitas di Indonesia, dengan Chevron sebagai produsen terbesar minyak di Indonesia dan Total sebagai produsen gas terbesar di Indonesia

Perusahaan minyak asing memegang andil cukup besar dalam eksploitasi migas Indonesia. BP Migas (Badan Pengelola Minyak dan Gas) mengatakan sekitar 85,4 persen dari 137 Wilayah Kerja pertambangan migas nasional saat ini dimiliki oleh perusahaan 
migas asing. Menurut BP Migas, perusahaan migas nasional hanya menguasai sekitar 14,6 persen wilayah kerja dan delapan persen di antaranya dikuasai Pertamina. Lima kontraktor asing terbesar di Indonesia adalah Exxon Mobil, Chevron, Shell, Total dan BP (Beyond Petroleum) dimana mereka menguasai cadangan minyak bumi 70 persen dan cadangan gas alam 80 persen serta memiliki kapasitas produksi 68 persen minyak bumi dan 82 persen gas alam.

Banyaknya jumlah perusahaan migas asing di Indonesia menyebabkan sedikitnya perusahaan migas nasional yang beroperasi di Indonesia. Dalam kapasitas produksi jumlah perusahaan nasional yang sedikit berdampak terhadap hasil ekspor Indonesia. Hasil dari produksi perusahaan migas asing di Indonesia tidak digunakan sepenuhnya untuk rakyat Indonesia. Ketika terjadi defisit untuk menutupi ketersediaan yang kurang di dalam negeri, Indonesia pada akhirnya mengimpor.

Pada tahun 1899, pihak swasta mendesak pemerintah Belanda untuk mengeluarkan Undang - undang mengenai pertambangan (Indische Mijnweet). Isi undang-undang pertambangan ini adalah memberikan izin pertambangan melalui sistem konsesi yang berlaku hingga 75 tahun. Sejak UU ini berlaku, perusahaan multinasional mulai berpartisipasi dalam mengeksploitasi sektor tambang Indonesia. Hal ini pun menandai masuknya Indonesia dalam jaringan perdagangan migas global. Dari dulu hingga kini jumlah perusahaan asing terus bertambah. Menurut BP Migas (Badan Pengelola Minyak dan Gas), sekitar 85,4 persen dari 137 Wilayah Kerja pertambangan migas nasional saat ini dimiliki oleh perusahaan migas asing. Perusahaan nasional hanya menguasai sekitar 14,6 persen Wilayah Kerja dan delapan persen di antaranya dikuasai Pertamina. Lima kontraktor asing terbesar di Indonesia adalah ExxonMobil, Chevron, Shell, Total dan BP (Beyond Petroleum) dimana mereka menguasai cadangan minyak bumi 70 persen dan cadangan gas alam 80 persen serta memiliki kapasitas produksi 68 persen minyak bumi dan 82 persen gas alam.

BP migas menyatakan banyaknya jumlah perusahaan migas asing akan membawa dampak positif terhadap lapangan pekerjaan di Indonesia. Namun disisi lain, hal ini juga membuat pemerintah tidak mandiri dalam menyediakan lapangan pekerjaan. Pada tahun 2001, keberadaan perusahaan migas asing di Indonesia semakin kuat. Ini terjadi karena di dalam pasal-pasal Undang-Undang No 22 Tahun 2001 banyak sekali ayat yang mempermudah perusahaan migas asing dalam melakukan usahanya di Indonesia. Didalam Undang-Undang No 22 Tahun 2001 pun dikatakan minyak dan gas alam yang di hasilkan oleh perusahaan migas asing dapat dikirimkan kembali ke negara asal perusahaan atau pun di jual kepada pembeli dengan penawaran tertinggi. Melihat realitas ini civil society (LSM) di Indonesia mengajukan banding kepada Mahkamah Konstitusi. Akhirnya Undang-Undang no. 22 tahun 2001 dihapus Mahkamah Konstitusi karena dianggap tidak sesuai dengan Undang Undang Dasar 1945. Selain itu, faktor lemahnya pengawasan pemerintah terhadap kegiatan yang di lakukan oleh perusahaan migas asing pun memperkuat posisi perusahaan asing di Indonesia. Akibatnya persediaan minyak dan gas alam semakin cepat habis.

\section{Besarnya Tingkat Net Ekspor Migas Indonesia}

Indonesia merupakan pelaku utama dan sudah dikenal dalam industri migas internasional. Sejak di temukannya sumber minyak di tahun 1885 , sektor minyak dan gas alam terus berkembang di Indonesia. Indonesia mencapai masa kejayaan dalam memproduksi minyak di periode 1977 sampai 1991 dengan total produk sebanyak 1,7 juta barel minyak perhari. Dalam komoditas gas, Indonesia sempat menjadi eksportir LNG (Liquid Natural Gas) terbesar di dunia pada tahun 2005 (EIA, 2013). ${ }^{14}$

Dengan berkembangnya zaman, penduduk dan teknologi, cadangan minyak Indonesia semakin menipis. Sehingga produksi minyakpun semakin berkurang. Namun, konsumsi

\footnotetext{
14 EIA(US Energy Information Administration, 2013, Indonesia Fact Sheet. Data di peroleh dari
} http://www.eia.gov/countries/analysisbriefs/Indonesia/indonesia.pdf 
minyak Indonesia terus menunjukkan peningkatan tiap tahunnya. Fenomena tersebut dapat dilihat pada grafik di bawah ini:

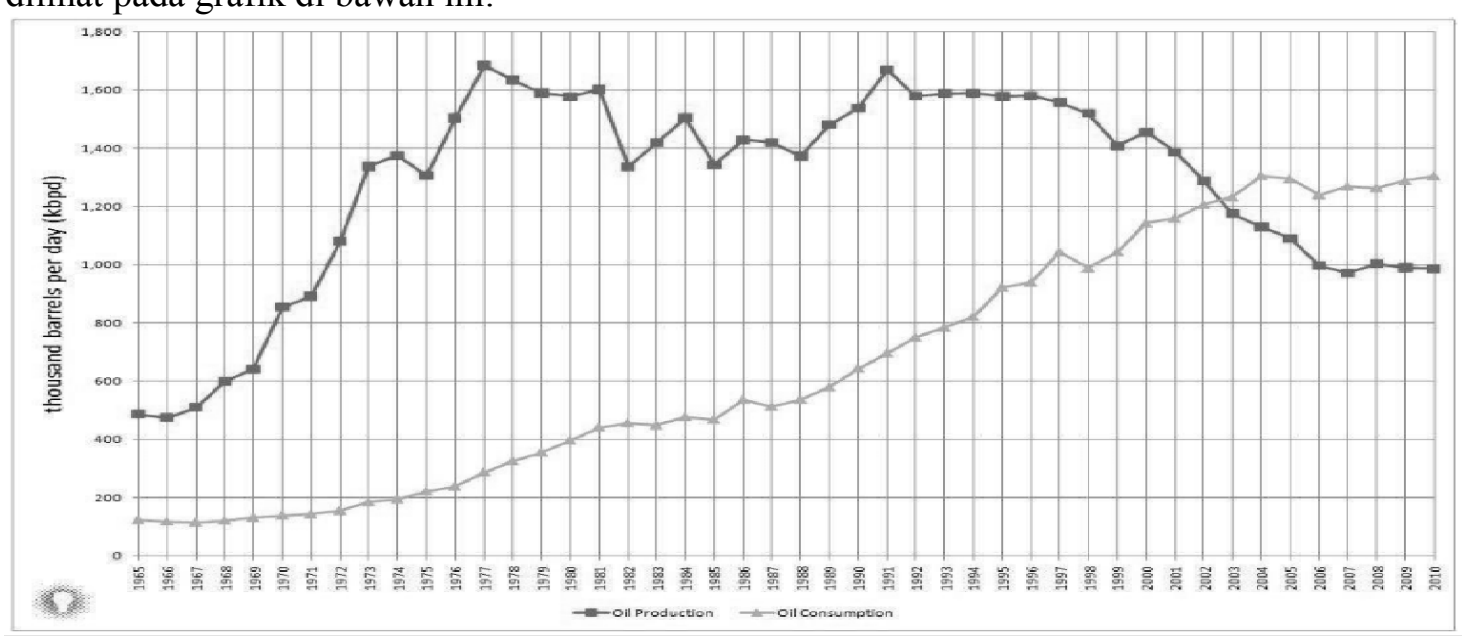

Gambar 2. Perbandingan Produksi dan Konsumsi Minyak Indonesia (1965-2010) Sumber : BP Statistical Review of World Energy, 2011

Grafik diatas menunjukan bahwa Indonesia pernah mencapai dua kali puncak produksi minyak yaitu pada tahun 1977 dan 1991 dengan produksi sebesar 1,7 juta barel per hari $(b p h)$. Setelah itu produksi minyak bumi Indonesia menurun dan mengalami stagnasi pada angka produksi 1 juta bph. Sebaliknya konsumsi minyak Indonesia terus mengalami peningkatan. Ini membuat produksi minyak bumi Indonesia tak mampu lagi memenuhi konsumsi minyak bumi dalam negeri di tahun 2002. Kemudian, Indonesia menjadi negara net-importir minyak bumi. Akhirnya, pada tahun 2008, Indonesia secara resmi keluar dari persatuan Negara-Negara Pengekspor Minyak (OPEC). Meskipun Indonesia keluar dari OPEC, tidak berarti sepenuhnya Indonesia menghentikan kegiatan ekspor migas. Indonesia tetap melakukan ekspor migas, namun jumlahnya tidak sebesar ketika menjadi anggota OPEC. Komoditas gas alam yang memiliki jumlah produksi yang cukup seimbang dengan laju konsumsinya. Hal ini dapat terlihat dalam grafik berikut:

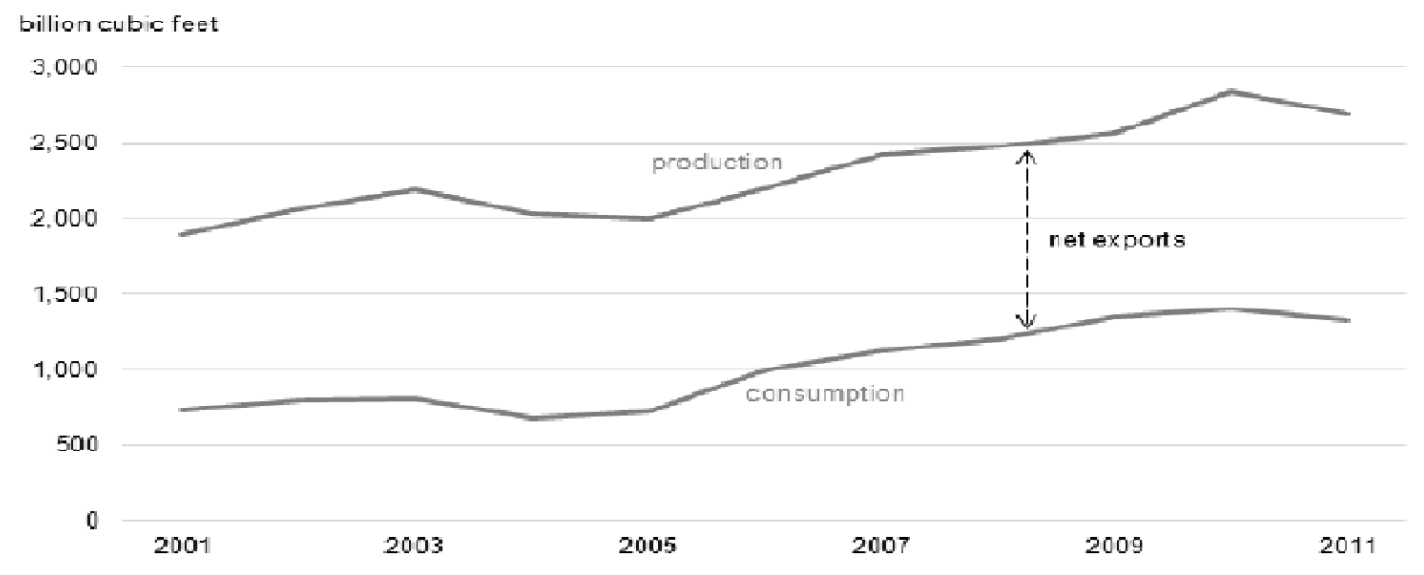

Gambar 3. Perbandingan Produksi dan Konsumsi Gas Alam Indonesia (2001-2011) Sumber : EIA(US) Energy Information, 2012

Grafik di atas menunjukkan bahwa produksi gas alam meningkat seiring seiring dengan konsumsi yang juga meningkat. Tingkat produksi gas alam Indonesia masih lebih banyak di bandingkan konsumsi gas alam. Sehingga Indonesia disebut sebagai net eksportir gas alam. Dalam rentang 10 tahun tersebut produksi tertinggi gas alam terjadi pada tahun 
2010 dengan jumlah sekitar 2,800 miliar kaki kubik (billion cubic feet/bcf). Konsumsi gas alam pun meningkat di tahun 2010 dengan jumlah sekitar 1,400 bcf.

Walaupun Indonesia memiliki cadangan gas yang besar namun konsumsi energi Indonesia di dominasi oleh bahan bakar minyak. Presentasi jenis energi yang di konsumsi dapat terlihat dalam grafik berikut:

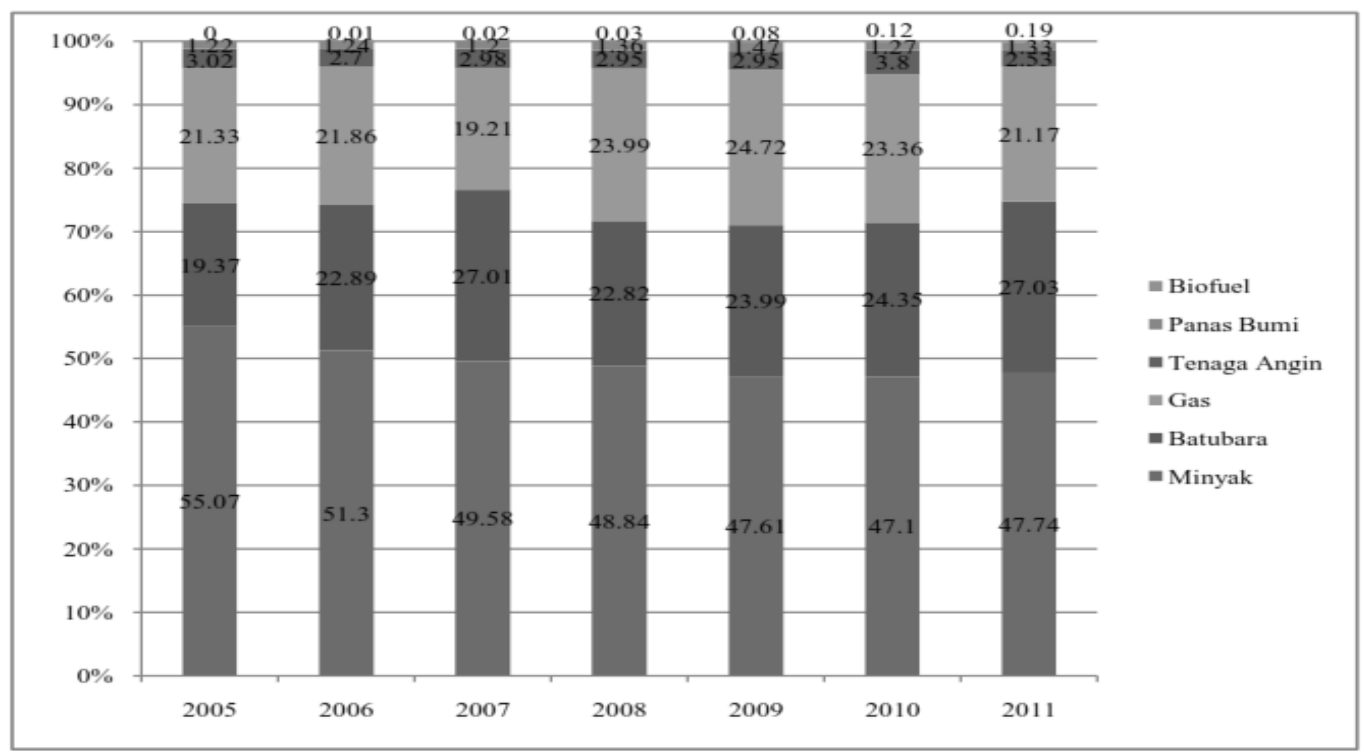

Gambar 4. Bauran Energi Primer Indonesia (2005-2011)

Sumber: Kementerian Energi dan Sumber Daya Mineral, 2012

Tidak semua minyak mentah yang dieksploitasi dari perut bumi Indonesia dapat diolah kilang-kilang minyak dalam negeri. Karena tidak semua spesifikasi minyak mentah cocok untuk diolah mengunakan teknologi di kilang minyak dalam negeri. Dari seluruh produksi crude oil Indonesia hanya sekitar 55 persen yang bisa diolah oleh kilang minyak Indonesia. Indonesia harus mengimpor minyak mentah yang cocok dengan spesifikasi kilang nasional dalam jumlah cukup besar. Secara keseluruhan, hingga akhir 2010 Indonesia bergantung pada pasokan minyak dari luar negeri sebanyak 70 persen.

Sejak tahun 2000 impor minyak Indonesia mulai menunjukkan peningkatan. Dapat dilihat pada gambar di bawah ini:

Tabel 1. Ekspor Impor Minyak Bumi Indonesia Tahun 2000-2011

\begin{tabular}{|c|c|c|c|}
\hline \multirow[t]{2}{*}{ Year } & Production & Export & Import \\
\hline & \multicolumn{3}{|c|}{ Thousand Barrel } \\
\hline 2000 & 517.489 & 223.500 & 78.615 \\
\hline 2001 & 489.306 & 241.612 & 117.168 \\
\hline 2002 & 456.026 & 218.115 & 124.148 \\
\hline 2003 & 419.255 & 189.095 & 137.127 \\
\hline 2004 & 400.554 & 178.869 & 148.490 \\
\hline 2005 & 386.483 & 159.703 & 164.007 \\
\hline 2006 & 367.049 & 134.960 & 116.232 \\
\hline 2007 & 348.348 & 135.267 & 115.812 \\
\hline 2008 & 357.501 & 134.872 & 95.100 \\
\hline 2009 & 346.323 & 132.223 & 120.119 \\
\hline 2010 & 344.888 & 134.473 & 101.093 \\
\hline 2011 & 329.265 & 135.572 & 96.862 \\
\hline
\end{tabular}

Sumber: Handbook of Energi \& Economic Statitics Indonesia, 2013 
Tabel 1 menunjukkan bahwa produksi minyak mentah Indonesia semakin menurun tiap tahunnya, dari produksi berjumlah 517,489 ribu barel menjadi 329,265 ribu barel. Ekspor minyak mentah Indonesia pun turut menurun seiring dengan turunnya jumlah produksi. Di sisi lain, nilai impor minyak Indonesia meningkat, walaupun memiliki pola yang tidak teratur. Dari total 78,615 ribu barel pada tahun 2000 meningkat menjadi 96,862 barel per hari di tahun 2011.

Data ekspor impor migas (untuk minyak) menunjukkan angka defisit (negatif). Hal ini disebabkan karena nilai konsumsi BBM Indonesia di dalam negeri lebih tinggi dibandingkan dengan nilai ekspor migas. Nilai ekspor migas yang rendah disebabkan karena Indonesia mengekspor minyak mentah yang harganya lebih rendah dibanding minyak yang sudah diolah. Hal ini berbanding terbalik dengan nilai impor migas. Indonesia memiliki nilai impor migas tinggi karena mengimpor minyak jadi bukan minyak mentah. Harga produk jadi pasti lebih tinggi produk mentah (Didin, 2013) ${ }^{15}$. Walaupun menjadi eksportir, ketika harga minyak dunia melonjak, Indonesi mengalami defisit anggaran dalam APBN. Alasannya karena jumlah minyak yang diimpor jauh lebih banyak.

\section{Hubungan Antara Banyaknya Perusahaan Asing yang Menguasai Blok Migas dengan Tingkat Ekspor Migas Indonesia}

Perusahaan asing masih mendominasi eksploitasi migas Indonesia, dimana 85,4 persen dari 137 blok pertambangan migas nasional saat ini kuasa penambangannya dimiliki oleh perusahaan migas asing. Kondisi ini sangat memperihatinkan, mengingat Indonesia merupakan negara yang memiliki cadangan migas dengan jumlah besar, namun hasilnya banyak dimanfaatkan untuk kepentingan luar bukan dalam negeri.

Meskipun saat ini Indonesia terhitung sebagai negara pengekspor terbesar gas dunia, namun menurut Ikatan Ahli Geologi Indonesia (IAGI) Indonesia diprediksikan akan menjadi negara net-importir gas pada tahun 2016. Perusahaan Listrik Negara (PLN) sempat mengemukakan rencana mereka untuk membeli gas dari Qatar di tahun 2012. ${ }^{16}$ Data statistik energi dan ekonomi Indonesia mencatat bahwa total produksi minyak bumi Indonesia selalu menurun tiap tahunnya. Pada tahun 2000 total produksi minyak bumi sebesar 517.489 juta barrel dan terus menurun sampai pada tahun 2011 sebesar 329.265 juta barrel. Dari total produksi minyak bumi tersebut, total ekspor Indonesia hanya sebagian saja. Misalnya pada tahun 2000, total ekspor minyak bumi Indonesia sebesar 223.500 juta barrel setara dengan $67 \%$ dari total produksi. Sedangkan pada tahun 2011 total ekspor minyak bumi Indonesia sebesar $41,17 \%$ dari total produksi minyak bumi, yakni sebanyak 135.572 juta barrel.

Sektor migas masih berpengaruh besar terhadap perekonomian, walaupun sumbangan industri atau sektor minyak dan gas bumi terhadap perekonomian Indonesia turun dibandingkan dengan periode jaya tahun 1973-1983. Pada tahun 2004, sebesar 9,3 dari PDB Indonesia bersumber dari sektor ini. Hampir seperempat dari nilai ekspor Indonesia berupa ekspor minyak dan gas bumi. Sektor migas masih menjadi penyumbang utama bagi penerimaan negara. Hampir seperlima dari pajak penghasilan pun dipungut dari sektor ini. Kehadiran perusahaan-perusahaan Migas asing di Indonesia dengan tingkat teknologi canggih dan modern memungkinkan perusahaan asing tersebut mengeksplorasi hasil tambang Indonesia seperti migas dalam skala besar. Sebagai contoh misalnya, Chevron sebagai perusahaan migas asing terbesar Indonesia melakukan kegiatan eksplorasi meliputi area Sumatera, Laut Natuna, Laut Jawa, Selat Makasar dan Papua dengan total sembilan operator blok dan satu operator pemegang interest. Untuk dua blok di daerah Sumatera saja, mampu menghasilkan 340.026 barrel per hari atau lebih dari sepertiga total produksi harian

15 Prof Didin S.Damanhuri, Kuliah ekonomi politik FEM IPB Program Studi Ilmu Ekonomi, 2013

16 Merdeka.(2012), Indonesia akan mulai impor LNG tiga tahun lagi. Diperoleh tanggal 6 Februari 2013 dari http://www.merdeka.com/uang/indonesia-akan-mulai-impor-lng-tiga-tahunlagi.html 
Indonesia. Blok ini telah menghasilkan11 milyar barel minyak dalam kurun waktu 80 tahun. $^{17}$

Dari data pada gambar 4 dijelaskan bahwa tingkat ekspor migas Indonesia semakin menurun setiap tahunnya, namun di sisi lain peran perusahaan asing sangat dominan dalam kegiatan eksplorasi migas Indonesia dari tahun ketahunnya. Pemerintah mengatakan pendapatan dari hasil ekspor migas Indonesia digunakan untuk menutupi biaya impor migas yang dilakukan Indonesia. Nilai konsumsi BBM Indonesia di dalam negeri sangat tinggi dibandingkan dengan nilai ekspor migas.

Banyaknya jumlah perusahaan asing dan besarnya eksplorasi yang dilakukan oleh perusahaan migas asing di Indonesia sangat bertolak belakang dengan kecilnya tingkat ekspor Migas di Indonesia. Akibat banyaknya perusahaan asing ini menyebabkan perusahaan migas negara seperti Pertamina memiliki porsi eksplorasi migas yang semakin sedikit. Sehingga menyebabkan nilai migas yang diekspor Indonesia semakin menurun tiap tahunnya.

Tingkat ekspor yang semakin sedikit dan tingkat impor yang semakin besar menyebabkan pemerintah mengambil kebijakan menaikkan harga BBM agar subsidi migas yang selama ini dikeluarkan pemerintah tidak menyebabkan defisit Anggaran Pendapatan dan Belanja Negara (APBN). Dengan cadangan migas Indonesia yang sedikit ditambah semakin banyaknya perusahaan asing yang menguasai blok migas Indonesia membuat tingkat nilai ekspor migas Indonesia semakin sedikit. Dengan kata lain, semakin banyaknya perusahaan asing yang menguasai blok migas Indonesia memiliki hubungan negatif dengan tingkat nilai ekspor minyak Indonesia. Ini berarti, semakin banyak perusahaan asing yang menguasi blok migas Indonesia akan menyebabkan tingkat nilai ekspor Indonesia semakin sedikit, sehingga pendapatan ekspor Indonesia dari sektor migas semakin kecil.

\section{KESIMPULAN DAN SARAN}

\section{Simpulan}

Keberadaan dan jumlah perusahaan migas asing mempengaruhi tingkat nilai ekspor migas Indonesia. Hal ini berarti semakin banyaknya perusahaan asing yang menguasai blok Migas Indonesia, maka tingkat nilai ekspor migas Indonesia juga akan semakin sedikit. Sebab lahan-lahan tambang migas yang seharusnya dikuasai dan dikelola oleh perusahaan migas nasional untuk diekspor hasil migasnya mayoritas hak eksploitasinya dikuasai perusahaan asing. Akibatnya perusahaan migas negara seperti Pertamina memiliki porsi eksplorasi migas yang semakin sedikit. Sehingga menyebabkan nilai migas yang diekspor Indonesia semakin menurun tiap tahunnya. Jika nilai ekpor Migas Indonesia ingin lebih tinggi, selain meningkatkan teknologi, pemerintah Indonesia harus berani merenegosiasi terkait hak eksploitasi perusahaan asing atas blok migas di Indonesia.

\section{Saran}

Saran-saran yang dapat diberikan oleh penulis kepada penulis selanjutnya antara lain:

1. Data yang digunakan dalam makalah ini masih terbatas hanya sampai pada tahun 2011, sehingga kurang menggambarkan kondisi kekinian yang dapat berbeda dari tahun-tahun sebelumnya.

2. Penelitian perlu menambahkan metode kuantitatif karena analisis yang digunakan dalam penelitian ini belum menggunakan alat analisis kuantitatif, hanya menggunakan analisis kualitatif dan deskriptif.

\footnotetext{
17 op.cit. Chevron, hal.2
} 


\section{DAFTAR PUSTAKA}

Berdikari. 2013. Manipulasi Para Imperalis Minyak. (http://www.berdikarionline.com/kabar-rakyat/20120531/manipulasi-paraimperialis-minyak.html\#ixzz2kzdo7dDDArtikel Online), diakses 8 Maret 2014.

BP Statistical Review of World 2011. (http://www.bp.com/liveassets/bp_internet/china/bpchina_english/STAGING/local assets/downloads_pdfs/statistical_review_of_world_energy_full_report_2011.pdf ), diakses 4 Maret 2014.

Damanhuri, DS. 2010. Ekonomi Politik dan Pembangunan. IPB Press. Bogor.

EIA (US Energy Information Administration). 2013. Indonesia Fact Sheet. http://www.eia.gov/countries/analysisbriefs/Indonesia/indonesia.pdf diakses 4 Maret 2014

EIA U.S Energy Information and Administration. Annual Energy Review 2011.2011.

$\begin{array}{llll}\text { EIA U.S Energy Information } & 013 .\end{array}$ http://www.eia.gov/countries/analysisbriefs/Indonesia/indonesia.pdf diakses 4 Maret 2014.

Fauzi, A 2014. Valuasi Ekonomi dan Penilaian Kerusakan Sumber Daya Alam dan Lingkungan. IPB Press. Bogor.

Hady, H. 2001. Ekonomi Internasional : Teori dan Kebijakan Perdagangan Internasional. Buku kesatu. Ghalia Indonesia. Jakarta.

Handbook of Energi \& Economic Statitics Indonesia. 2013.

Kementerian Energi dan Sumber Daya Mineral. 2012. Handbook of Energi \& Economic Statitics Indonesia. Jakarta.

Komalasari, E. 2013. Peranan Perusahaan Migas Asing terhadap Ketersediaan Energi Indonesia. Skripsi Sarjana. Fakultas Ilmu Sosial dan Ilmu Politik Universitas Hasanudin, Makasar.

Lairson, Thomas D and D Skidmore. 2003. "The Political Economy of American Hegemony: 1938-1973”, ins: International Political Economy: the Struggle for Power and Wealth. Orlando: Harcourt Brace College Publishers. Ch. 4.

Magdoff, H. 1978. "The Multinational Corporation and Development - A Contradiction?" dalam Imperialism: from the Colonial Age to the Present. New York: Monthly Preview Press.

Merdeka. 2012. Indonesia akan mulai impor LNG tiga tahun lagi. http://www.merdeka.com/uang/indonesia-akan-mulai-impor-lng-tiga tahunlagi.html, diakses 18 Maret 2014.

Novianto P. 2012. Perkembangan Perusahaan MNC. http://prima-a-nfisip09.web.unair.ac.id/artikel detail-46437-Umum

Kemunculan\%20dan\%20Perkembangam\%20Perusahaan\%20Multinasional\%20\%2 $8 \mathrm{MNC} \% 29 . \mathrm{html}$, diakses 6 Maret 2014.

Oktaviani, R dan Novianti. 2009. Teori Perdagangan Internasional dan Aplikasinya di Indonesia. Departemen Ilmu Ekonomi FEM IPB. Bogor.

Republik Indonesia. Undang-Undang Nomor 44 Tahun 1960 tentang Pertambangan Minyak dan Gas Bumi.

Seftyandra, F. 2013. Analisis Faktor- Faktor Yang Mempengaruhi Penerimaan Negara Bukan Pajak (PNBP) Subsektor Migas Periode 2001-2011.Skripsi Sarjana. Departemen Ilmu Ekonomi, Fakultas Ekonomi Manajemen, Institut Pertanian Bogor, Bogor. 